Article

\title{
In Vitro Evaluation of Different Dietary Methane Mitigation Strategies
}

\author{
Juana C. Chagas, Mohammad Ramin and Sophie J. Krizsan * \\ Department of Agricultural Research for Northern Sweden, Swedish University of Agricultural Sciences (SLU), \\ Skogsmarksgränd, 90183 Umeå, Sweden; juana.chagas@slu.se (J.C.C.); mohammad.ramin@slu.se (M.R.) \\ * Correspondence: sophie.krizsan@slu.se; Tel.: +46-90-7868748
}

Received: 15 October 2019; Accepted: 5 December 2019; Published: 11 December 2019

Simple Summary: Dietary methane mitigation strategies do not necessarily make food production from ruminants more energy-efficient, but reducing methane $\left(\mathrm{CH}_{4}\right)$ in the atmosphere immediately slows down global warming, helping to keep it within $2{ }^{\circ} \mathrm{C}$ above the pre-industrial baseline. There is no single most efficient strategy for mitigating enteric $\mathrm{CH}_{4}$ production from domestic ruminants on forage-based diets. This study assessed a wide variety of dietary $\mathrm{CH}_{4}$ mitigation strategies in the laboratory, to provide background for future studies with live animals on the efficiency and feasibility of dietary manipulation strategies to reduce $\mathrm{CH}_{4}$ production. Among different chemical and plant-derived inhibitors and potential $\mathrm{CH}_{4}$-reducing diets assessed, inclusion of the natural antimethanogenic macroalga Asparagopsis taxiformis showed the strongest, and dose-dependent, $\mathrm{CH}_{4}$ mitigating effect, with the least impact on rumen fermentation parameters. Thus, applying Asparagopsis taxiformis at a low daily dose was the best potential dietary mitigation strategy tested, with promising long-term effects, and should be further studied in diets for lactating dairy cows.

\begin{abstract}
We assessed and ranked different dietary strategies for mitigating methane $\left(\mathrm{CH}_{4}\right)$ emissions and other fermentation parameters, using an automated gas system in two in vitro experiments. In experiment 1 , a wide range of dietary $\mathrm{CH}_{4}$ mitigation strategies was tested. In experiment 2, the two most promising $\mathrm{CH}_{4}$ inhibitory compounds from experiment 1 were tested in a dose-response study. In experiment 1 , the chemical compounds 2-nitroethanol, nitrate, propynoic acid, p-coumaric acid, bromoform, and Asparagopsis taxiformis (AT) decreased predicted in vivo $\mathrm{CH}_{4}$ production (1.30, $21.3,13.9,24.2,2.00$, and $0.20 \mathrm{~mL} / \mathrm{g} \mathrm{DM}$, respectively) compared with the control diet $(38.7 \mathrm{~mL} / \mathrm{g}$ $\mathrm{DM})$. The 2-nitroethanol and AT treatments had lower molar proportions of acetate and higher molar proportions of propionate and butyrate compared with the control diet. In experiment 2, predicted in vivo $\mathrm{CH}_{4}$ production decreased curvilinearly, molar proportions of acetate decreased, and propionate and butyrate proportions increased curvilinearly with increased levels of AT and 2-nitroethanol. Thus 2-nitroethanol and AT were the most efficient strategies to reduce $\mathrm{CH}_{4}$ emissions in vitro, and AT inclusion additionally showed a strong dose-dependent $\mathrm{CH}_{4}$ mitigating effect, with the least impact on rumen fermentation parameters.
\end{abstract}

Keywords: antimethanogenic; chemical inhibition; global warming; halogenated compound; macroalgae; methane production; methanogenic inhibitor; plant inhibitory compound

\section{Introduction}

The global population is growing and, although there is enough food in the world today, there are major differences in how people live. Meat and milk from ruminants are high-quality foods and a large proportion of their production is based on grass, but production is still resource-intensive. Future intensification of agriculture can reinforce negative effects such as greenhouse gas (GHG) emissions, the main contributor to climate change through global warming [1,2]. 
Methane $\left(\mathrm{CH}_{4}\right)$ is a powerful GHG that plays a key part in global climate change and concentrations have been rising rapidly in the atmosphere over the past decade. Recently published data based on radioactive carbon $\left(\mathrm{C}^{14}\right)$ content in $\mathrm{CH}_{4}$ indicate that anthropogenic emissions of $\mathrm{CH}_{4}$ in recent decades have been higher than previously estimated [3]. Satellite data [4] suggest that the increased global $\mathrm{CH}_{4}$ emissions in the period 2005-2015 were mostly due to increased extraction of shale gas, and that the natural gas and oil industry contributes twice as much $\mathrm{CH}_{4}$ emissions as animal agriculture.

Methanogenesis in the rumen is an essential metabolic process required to remove molecular hydrogen generated during fermentation. The production of $\mathrm{CH}_{4}$ is influenced by animal species, age, management, and diet. The Rumen Census project sequenced a wide variety of rumen and camelid foregut microbial communities in many samples from a wide variety of animal species and countries, to identify factors such as diet, host species, or geography causing the greatest variation in $\mathrm{CH}_{4}$ emissions [5]. The results showed that rumen archaeal diversity was similar irrespective of host or diet, and a core rumen bacterial population of $67 \%$ of the community occurred irrespective of host or diet. The main diversity changes in other bacteria present were caused by diet, and not host genetics [6]. Although dietary strategies for mitigating enteric $\mathrm{CH}_{4}$ production in ruminants have been intensively studied, no single most efficient dietary strategy has been identified for dairy cows on forage-based diets.

Methane losses from typical dairy cow diets are 6-7\% of gross energy intake, but losses are approximately $3 \%$ in feedlot situations, indicating that feeding high-concentrate diets can reduce $\mathrm{CH}_{4}$ production [7]. However, recent data indicate that the effect on $\mathrm{CH}_{4}$ production of including more grain in dairy cows diets is small [8] and use of this strategy can therefore be questioned. Use of antimethanogenics or plant inhibitory compounds in ruminant diets can also reduce GHG emissions, and has been suggested as an effective and feasible strategy in the livestock sector [9]. Dietary mitigation strategies do not necessarily make food production from ruminants more energy-efficient, but they reduce $\mathrm{CH}_{4}$ emissions to the atmosphere and thus immediately slow down global warming [10], contributing to keep the planet within $2{ }^{\circ} \mathrm{C}$ of the pre-industrial baseline [11]. The use of $\mathrm{CH}_{4}$ inhibitors might be the most immediate and efficient strategy to reduce $\mathrm{CH}_{4}$ emissions from dairy cows. The most successful inhibitor suggested in vivo so far is 3-nitroxypropanol that has showed $\mathrm{CH}_{4}$ reducing effects when provided to dairy cows in a low dose [12]. The tropical macroalgae Asparagopsis Taxiformis is a recent and natural supplement that has shown very promising $\mathrm{CH}_{4}$ inhibitory effects in vitro [13].

In vitro gas production technique has been developed to evaluate factors influencing digestibility and fermentation kinetics from feeds. The technique has been used to estimate $\mathrm{CH}_{4}$ emission with the advantage of screening large number of samples, providing large amount of data points, and allowing accurate predictions of in vivo $\mathrm{CH}_{4}$ production [14].

This study assessed and ranked a wide variety of dietary $\mathrm{CH}_{4}$ mitigation strategies using an automated gas in vitro system, in order to provide background for future in vivo evaluations of dietary manipulation strategies for efficiently reducing $\mathrm{CH}_{4}$ production from domestic ruminants.

\section{Materials and Methods}

Two in vitro experiments were conducted to assess different dietary antimethanogenic compounds. In experiment 1 , the dietary $\mathrm{CH}_{4}$ mitigating strategies tested comprised six chemical inhibitory compounds at two levels, three plant-derived inhibitory treatments at two levels, five different potentially $\mathrm{CH}_{4}$-reducing diets with the active ingredients in two levels except for one of the diets, and two typical grass silage fermentation acids at two levels to mimic different silage fermentation qualities. In experiment 2, the two most promising $\mathrm{CH}_{4}$ inhibitory treatments from experiment 1 were tested in a dose-response experiment designed to represent a wide range of treatment levels.

\subsection{Experimental Treatments}

\subsubsection{Experiment 1}


All experimental diets were composed from a control diet that consisted of timothy grass (Phleum pratense), rolled barley (Hordeum vulgare), and rapeseed (Brassica napus) meal in a ratio of 545:363:92 $\mathrm{g} / \mathrm{kg}$ diet dry matter (DM). The grass and rolled barley originated from Röbäcksdalens research farm in Umeå $\left(63^{\circ} 45^{\prime} \mathrm{N}, 20^{\circ} 17^{\prime} \mathrm{E}\right)$, Sweden. The rapeseed meal was a commercial solvent-extracted and heat-moisture-treated protein supplement ExPro-00SF (Aarhus Karlshamn $\mathrm{AB}$, Malmö, Sweden). All potential dietary $\mathrm{CH}_{4}$ mitigating strategies tested in experiment 1 are listed in Table 1. The chemical compounds 2-nitroethanol (2-NE), propynoic acid, ferulic acid, p-coumaric acid, and bromoform (Sigma-Aldrich Sweden AB, Stockholm, Sweden) were added without replacing any DM of the control diet. Nitrate was added to the control diet to represent one level of $21 \mathrm{~g} \mathrm{NO}_{3} / \mathrm{kg}$ $\mathrm{DM}$ or $0.0890 \mathrm{~g} \mathrm{Ca}\left(\mathrm{NO}_{3}\right)_{2} \times 4 \mathrm{H}_{2} \mathrm{O} / \mathrm{g} \mathrm{DM}$ (Sigma-Aldrich Sweden $\mathrm{AB}$, Stockholm, Sweden). The nitrate treatment was compared with a zero-nitrate treatment in which $0.0350 \mathrm{~g}$ urea/g DM and $0.051 \mathrm{~g}$ $\mathrm{CaCO}_{3} / \mathrm{g} \mathrm{DM}$ (J.T. Baker BV, Deventer, The Netherland) were added to the control diet to achieve an isonitrogenous and equivalent diet (159 g crude protein $(\mathrm{CP}) / \mathrm{kg} \mathrm{DM})$. The plant-derived compounds rowan (Sorbus aucuparia) berries and the forb fireweed (Chamerion angustifolium) were added to replace grass and barley in the control diet, such that the ratio of forage:concentrate was kept constant relative to all other diets. These ingredients were collected in Umeå $\left(63^{\circ} \mathrm{N}, 20^{\circ} \mathrm{E}\right)$, Sweden in October and July 2018, respectively. The red seaweed Asparagopsis taxiformis (AT) was added in such a small dose in both levels of the treatment that no replacement of control dietary ingredients was made. The seaweed was harvested in the Azores ( $\left.38.6^{\circ} \mathrm{N}, 28^{\circ} \mathrm{W}\right)$, Portugal, in October 2018. Replacements in the potentially $\mathrm{CH}_{4}$-reducing diets were also made so that the forage:concentrate ratio was kept constant relative to all other diets and to contain $160 \mathrm{~g} \mathrm{CP} / \mathrm{kg}$ diet DM. Rapeseed oil and oats (Avena sativa) were added to replace grass and barley on a DM basis. These ingredients were also collected in Umeå in July 2018. Dried distiller's grains (Agrodrank 90, Agroetanol, Östergötland, Sweden) replaced rapeseed meal in the control diet and was added to represent an increment of $20 \mathrm{~g} / \mathrm{kg} \mathrm{DM}$ in CP between the levels (CP concentration $160 \mathrm{~g} / \mathrm{kg}$ DM and $180 \mathrm{~g} / \mathrm{kg} \mathrm{DM}$, respectively). The CP concentration was made iso-nitrogenous to the control diet for the lowest level when dried distiller's grain replaced rapeseed meal.

Table 1. Experimental treatments evaluated in vitro in experiment 1 for methane $\left(\mathrm{CH}_{4}\right)$ mitigation potential.

\begin{tabular}{ccc}
\hline Treatments & \multicolumn{2}{c}{ Levels } \\
\hline Chemical compounds & $5 \mathrm{mM}$ & $10 \mathrm{mM}$ \\
2-nitroethanol & None & $21 \mathrm{~g} / \mathrm{kg} \mathrm{DM}$ \\
Nitrate & $2 \mathrm{mM}$ & $4 \mathrm{mM}$ \\
Propynoic acid & $10 \mathrm{mM}$ & $20 \mathrm{mM}$ \\
Ferulic acid & $10 \mathrm{mM}$ & $20 \mathrm{mM}$ \\
p-Coumaric acid & $1.5 \mathrm{mg} / \mathrm{g} \mathrm{DM}$ & $3 \mathrm{mg} / \mathrm{g} \mathrm{DM}$ \\
Bromoform & & \\
Plant-derived treatments & $50 \mathrm{~g} / \mathrm{kg} \mathrm{DM}$ & $100 \mathrm{~g} / \mathrm{kg} \mathrm{DM}$ \\
Rowan berries & $50 \mathrm{~g} / \mathrm{kg} \mathrm{DM}$ & $100 \mathrm{~g} / \mathrm{kg} \mathrm{DM}$ \\
Fireweed & $10 \mathrm{~g} / \mathrm{kg} \mathrm{OM}$ & $20 \mathrm{~g} / \mathrm{kg} \mathrm{OM}$ \\
Asparagopsis taxiformis & & \\
Potentially CH & & \\
Rapeducing treatments oil & $40 \mathrm{~g} / \mathrm{kg} \mathrm{DM}$ & $80 \mathrm{~g} / \mathrm{kg} \mathrm{DM}$ \\
Dried distiller's grain & $90 \mathrm{~g} / \mathrm{kg} \mathrm{DM}$ & $180 \mathrm{~g} / \mathrm{kg} \mathrm{DM}$ \\
Barley:oat & $175: 175 \mathrm{~g} / \mathrm{kg}$ & $0: 350 \mathrm{~g} / \mathrm{kg}$ \\
Maize silage:grass & $275: 275 \mathrm{~g} / \mathrm{kg}$ & $545: 0 \mathrm{~g} / \mathrm{kg}$ \\
Red clover:grass & $275: 275 \mathrm{~g} / \mathrm{kg}$ & $\mathrm{None}$ \\
Lactic acid & $60 \mathrm{~g} / \mathrm{kg} \mathrm{DM}$ & $120 \mathrm{~g} / \mathrm{kg} \mathrm{DM}$ \\
Lactic acid + acetic acid & $80+30 \mathrm{~g} \mathrm{DM}$ & $80+60 \mathrm{~g} \mathrm{DM}$ \\
\hline
\end{tabular}

$\mathrm{DM}=$ dry matter; ${ }^{1} 0.035 \mathrm{~g}$ of urea $+0.051 \mathrm{~g}$ of $\mathrm{CaCO}_{3}$ on DM basis included in control diet in comparison with nitrate treatment; ${ }^{2} 0.089 \% \mathrm{Ca}\left(\mathrm{NO}_{3}\right)_{2} \times 4 \mathrm{H}_{2} \mathrm{O}$ on DM basis; ${ }^{3}$ Urea was added to correct $\mathrm{CP}$ at $160 \mathrm{~g} / \mathrm{kg} \mathrm{DM} ;{ }^{4}$ Urea was added to correct $\mathrm{CP}$ at $160 \mathrm{~g} / \mathrm{kg}$ DM. 
In the treatments where maize (Zea mays) silage replaced grass silage, urea was added to make diets isonitrogenous to the control diet. No correction of CP concentration was made in the diet when red clover (Trifolium pratense) replaced grass.

\subsubsection{Experiment 2}

In experiment 2 , AT $(0,0.06,0.13,0.25,0.5$, and $1.0 \mathrm{~g} / \mathrm{kg}$ of diet organic matter $(\mathrm{OM}))$ and $2-\mathrm{NE}$ $(0,0.3,0.7,1.3,2.6$, and $5.1 \mathrm{mM})$ were tested in a dose-response experiment comprising six different treatment levels. The same control diet as in experiment 1, of timothy, rolled barley, and rapeseed meal, was used in experiment 2.

\subsection{In Vitro Incubations}

The handling of animals in this experiment was approved by the Swedish Ethics Committee on Animal Research (Dnr A 32-16), represented by the Court of Appeal for Northern Norrland in Umeå, and the experiment was carried out in accordance with laws and regulations governing experiments performed with live animals in Sweden.

Two lactating Swedish Red cows, fed ad libitum on a diet of $600 \mathrm{~g} / \mathrm{kg}$ grass silage and $400 \mathrm{~g} / \mathrm{kg}$ concentrate on a DM basis (presenting chemical composition as $509 \mathrm{~g} / \mathrm{kg}$ of DM, $425 \mathrm{~g} / \mathrm{kg}$ NDF, and $171 \mathrm{~g} / \mathrm{kg} \mathrm{CP}$ ), were used as donor animals of rumen inoculum for all incubations. The rumen fluid from each cow was filtered separately using a double layer of cheesecloth into Thermos flasks that were pre-warmed and flushed with carbon dioxide $\left(\mathrm{CO}_{2}\right)$ prior to collection. Rumen fluid was transported to the laboratory within $15 \mathrm{~min}$. Equal amounts from each cow were immediately blended, strained through four layers of cheesecloth, and added to buffered mineral solution [15] including Peptone ${ }^{\mathrm{TM}}$ (pancreatic digested casein; Merck, Darmstadt, Germany) at $39{ }^{\circ} \mathrm{C}$ under constant mixing and $\mathrm{CO}_{2}$ flushing, to give a buffered rumen fluid solution with a rumen fluid:buffer ratio of 1:4 by volume.

Prior to each in vitro incubation, dietary ingredients were dried at $60{ }^{\circ} \mathrm{C}$ for $48 \mathrm{~h}$ and milled in a Retsch SM 2000 cutting mill (Retsch GmbH, Haan, Germany) to pass through a 1-mm screen. Then $1003 \pm 38 \mathrm{mg}$ of DM substrate were weighed into serum bottles flushed with $\mathrm{CO}_{2}$, and $60 \mathrm{~mL}$ of the previously prepared buffered rumen fluid were added. All bottles were placed in a water bath and gently and continuously agitated at $39^{\circ} \mathrm{C}$ during an incubation period of $48 \mathrm{~h}$.

These procedures were repeated for six runs in total and all samples were incubated, with three replicates of each sample. All runs included triplicate bottles with blanks (i.e., bottles with $60 \mathrm{~mL}$ of buffered rumen fluid with no sample or treatment in), and samples were randomly allocated to the in vitro incubation bottles and never incubated in the same bottle in more than one run.

\subsection{In Vitro Gas Production Measurements and Sampling}

Gas production was measured using a fully automated system (Gas Production Recorder, GPR-2, Version 1.0 2015, Wageningen UR), with readings made every $12 \mathrm{~min}$ and corrected to the normal air pressure $(101.3 \mathrm{kPa})[16]$.

Measurement of $\mathrm{CH}_{4}$ in vitro was performed according to Ramin and Huhtanen [14] on gas samples withdrawn during the incubation period $(0.2 \mathrm{~mL})$ from each bottle at $2,4,8,24,32$, and $48 \mathrm{~h}$. Concentration of $\mathrm{CH}_{4}$ was determined with a Varian Star $3400 \mathrm{CX}$ gas chromatograph (Varian Analytical Instruments, Walnut Creek, CA, USA) equipped with a thermal conductivity detector.

Liquid samples of $0.6 \mathrm{~mL}$ were collected from the bottles at 8,24 , and $48 \mathrm{~h}$ of incubation and immediately stored at $-20{ }^{\circ} \mathrm{C}$ until analysis of volatile fatty acids (VFA). Liquid samples for ammonia-nitrogen $\left(\mathrm{NH}_{3}-\mathrm{N}\right)$ analysis were taken at 8 and $24 \mathrm{~h}$ of incubation, and also stored at $-20^{\circ} \mathrm{C}$ before further analysis. Liquid samples from the replicate treatments between runs were pooled before $\mathrm{NH}_{3}-\mathrm{N}$ and VFA analysis.

After $48 \mathrm{~h}$ of incubation, all bottles were removed from the water bath and placed on ice to stop fermentation. The residue was used for in vitro determination of true organic matter digestibility (TOMD). 


\subsection{Chemical Analysis}

The concentrations of DM and $\mathrm{OM}$ in the individual dietary ingredients were quantified by AOAC [17] method 930.15 and method 942.05 , respectively. Concentrations of nitrogen were determined by Kjeldahl digestion of $1000 \mathrm{mg}$ sample in $12 \mathrm{M}$ sulfuric acid using Foss Tecator Kjeltabs $\mathrm{Cu}$ (Höganäs, Sweden) in a Block Digestion 28 system (SEAL Analytical Ltd., Mequon, WI, USA), followed by determination of total nitrogen by continuous flow analysis using an Auto Analyzer 3 (SEAL Analytical Ltd., Mequon, WI, USA). The samples were analyzed for neutral detergent fiber (NDF) using a heat-stable $\alpha$-amylase [18] in an ANKOM200 Fiber Analyzer (Ankom Technology Corp., Macedon, NY, USA).

In vitro TOMD was determined for all samples in all runs by analyzing ash-free NDF concentrations in the residues using 07-11/5 Sefar Petex (Sefar AG, Heiden, Switzerland) in situ bags according to Krizsan et al. [19].

Individual VFA concentrations in rumen fluid samples were determined using a Waters Alliance 2795 UPLC system as described by Puhakka et al. [20], and $\mathrm{NH}_{3}-\mathrm{N}$ concentration according to the method provided by SEAL Analytical (Method no. G-102-93 multitest MT7) using AutoAnalyzer 3.

Bromoform concentration in AT was analyzed according to Roque et al. [21] using an Agilent 7890B GC applied to Agilent 7000C triple quad Mass Spectrometer equipped with a ZB-5ms column (Agilent Technologies, Inc. Santa Clara, CA, USA).

\subsection{Calculations}

Mean blank gas production within run was subtracted from sample gas production. In vivo predicted $\mathrm{CH}_{4}$ production was calculated as described by Ramin and Huhtanen [14] as:

$$
\mathrm{CH}_{4}=265 \times \mathrm{CH}_{4} \text { concentration }+ \text { total gas production } \times \mathrm{CH}_{4} \text { concentration } \times 0.55
$$

where total gas production is in $\mathrm{mL} / \mathrm{g}$ sample, 265 is the total headspace volume $(\mathrm{mL})$, and 0.55 is the ratio of $\mathrm{CH}_{4}$ emissions in the outflow gas from the in vitro system. A mean retention time of $50 \mathrm{~h}(20 \mathrm{~h}$ in the first compartment and $30 \mathrm{~h}$ in the second compartment), corresponding to the maintenance level of feed intake, was used in model simulations.

Total VFA (TVFA) production was calculated as: the molar proportion of individual VFA were calculated related to TVFA.

$$
\begin{aligned}
\text { TVFA }(\mathrm{mmol})= & \left(\sum \text { individual VFA concentration }- \text { mean of blank VFA }\right) \times \\
& 0.06(\text { amount of buffered rumen fluid })
\end{aligned}
$$

The molar proportion of individual VFA were calculated related to TVFA.

The in vitro TOMD was calculated as:

$$
\operatorname{TOMD}(\mathrm{g} / \mathrm{kg})=\frac{\text { incubated OM }(\mathrm{g})-\mathrm{NDF} \text { residue corrected for ash and blank }(\mathrm{g})}{1000 \times \text { incubated OM }(\mathrm{g})}
$$

\subsection{Statistical Analysis}

Data on in vivo predicted $\mathrm{CH}_{4}$ production and in vitro TOMD from Experiment 1 were analyzed using the MIXED procedure in SAS (SAS Institute Inc., Cary, NC, version 9.4), by a model correcting for random effect of bottle and fixed effect of run and treatment:

$$
Y_{i j k}=\mu+T_{i}+R_{j}+B_{k}+e_{i j k}
$$

where $Y_{i j k}$ is dependent variable $i j k$, $\mu$ is overall mean, $T_{i}$ is treatment $i, R_{j}$ is run $j, B_{k}$ is bottle $k$, and $e_{i j k}$ $\sim \mathrm{N}\left(0, \sigma_{e}^{2}\right)$ is the random residual error. Orthogonal contrasts were included for evaluation of control diet vs. treatment and of linear responses to level of treatment. 
Data on measured VFA and $\mathrm{NH}_{3}-\mathrm{N}$ concentrations from Experiment 1 were evaluated in a repeated measurements model using the Toeplitz function in the MIXED procedure in SAS (SAS Institute Inc., Cary, NC, USA, version 9.4) (level within treatment was used as subject). The model accounted for effects of treatment and time, and interactions between treatment and time:

$$
\mathrm{y}_{\mathrm{ij}}=\mu+\mathrm{T}_{\mathrm{i}}+\mathrm{A}_{\mathrm{j}}+(\mathrm{TA})_{\mathrm{ij}}+\mathrm{e}_{\mathrm{ij}}
$$

where $y_{i j}$ is the dependent variable $i j, \mu$ is overall mean, $T_{i}$ is treatment $i, A_{j}$ is time $j,(T A)_{i j}$ is interaction between treatment $\mathrm{i}$ and time $\mathrm{j}$, and $\mathrm{e}_{\mathrm{ij}} \sim \mathrm{N}\left(0, \sigma_{e}^{2}\right)$ is the random residual error.

Data on predicted in vivo $\mathrm{CH}_{4}$ production, in vitro TOMD, total VFA (TVFA), and molar proportions of individual VFA and $\mathrm{NH}_{3}-\mathrm{N}$ from experiment 2 were subjected to linear and quadratic regression analysis using the REG procedure in SAS (SAS Institute Inc., Cary, NC, USA, version 9.4). Best fit was judged from lowest root mean square error and highest adjusted $\mathrm{R}^{2}$.

Effects were considered statistically significant at $p$-value $\leq 0.05$.

\section{Results}

The chemical composition of the control diet and the potential $\mathrm{CH}_{4}$ reducing diets is shown in Table 2. The AT bromoform concentration was $6.84 \mathrm{mg} / \mathrm{g}$ DM.

Table 2. Chemical composition $(\mathrm{g} / \mathrm{kg} \mathrm{DM})$ of control and potential methane $\left(\mathrm{CH}_{4}\right)$ reducing diets evaluated in vitro in experiment 1.

\begin{tabular}{ccccc}
\hline Treatment & Level & Organic Matter & Crude Protein & Neutral Detergent Fiber \\
\hline Control diet & - & 944 & 160 & 387 \\
Rapeseed oil & $40 \mathrm{~g} / \mathrm{kg} \mathrm{DM}$ & 906 & 154 & 372 \\
Rapeseed oil & $80 \mathrm{~g} / \mathrm{kg} \mathrm{DM}$ & 869 & 149 & 356 \\
Dried distiller's grain & $90 \mathrm{~g} / \mathrm{kg} \mathrm{DM}$ & 946 & 161 & 378 \\
Dried distiller's grain & $180 \mathrm{~g} / \mathrm{kg} \mathrm{DM}$ & 946 & 181 & 366 \\
Barley: oat & $175: 175 \mathrm{~g} / \mathrm{kg}$ & 944 & 165 & 385 \\
Barley: oat & $0: 350 \mathrm{~g} / \mathrm{kg}$ & 944 & 170 & 383 \\
Maize silage: grass & $275: 275 \mathrm{~g} / \mathrm{kg}$ & 954 & 160 & 355 \\
Maize silage: grass & $545: 0 \mathrm{~g} / \mathrm{kg}$ & 963 & 160 & 323 \\
Red clover: grass & $275: 275 \mathrm{~g} / \mathrm{kg}$ & 932 & 171 & 345 \\
Lactic acid & $60 \mathrm{~g} / \mathrm{kg} \mathrm{DM}$ & 887 & 151 & 364 \\
Lactic acid & $120 \mathrm{~g} / \mathrm{kg} \mathrm{DM}$ & 831 & 143 & 341 \\
Lactic acid + acetic acid & $80+30 \mathrm{~g} / \mathrm{kg} \mathrm{DM}$ & 840 & 144 & 345 \\
Lactic acid + acetic acid & $80+60 \mathrm{~g} / \mathrm{kg} \mathrm{DM}$ & 812 & 140 & 333 \\
\hline
\end{tabular}

$\mathrm{NDF}=$ neutral detergent fibre.

\subsection{Experiment 1}

Predicted in vivo $\mathrm{CH}_{4}$ production derived from analysis of $48 \mathrm{~h}$ gas in in vitro incubation of the control diet was $38.7 \mathrm{~mL} / \mathrm{g}$ DM, in vitro TOMD was $867 \mathrm{~g} / \mathrm{kg}$, TVFA was $3.62 \mathrm{mmol}$, and molar proportion of acetate, butyrate, and propionate was 583, 125, and $237 \mathrm{mmol} / \mathrm{mol}$, respectively. In comparison with the control diet the chemical compounds 2-NE, nitrate, propynoic acid, p-coumaric acid, bromoform, and the plant compound AT, decreased $(p \leq 0.01)$ in vivo $\mathrm{CH}_{4}$ predicted production (Table 3). Addition of 2-NE, bromoform, and AT gave the strongest inhibition $(p<0.01)$ of predicted in vivo $\mathrm{CH}_{4}$ production among all experimental treatments (97\%, 95\%, and 99\% reduction in the value for the control diet). The reduction in predicted in vivo $\mathrm{CH}_{4}$ production achieved by the other compounds ranged between $38 \%$ and $64 \%$ of the value for the control diet. Surprisingly, none of the potential $\mathrm{CH}_{4}$ reducing diets or lactic acid and acetic acid addition affected $\mathrm{CH}_{4}$ production in this study $(p \geq 0.20)$. In vitro TOMD was negatively affected by the chemical compounds $p$-coumaric acid and bromoform $(p<0.01)$, while rapeseed oil inclusion in the diet increased in vitro TOMD compared with the control diet $(p=0.04)$. Propynoic acid and bromoform decreased $(p \leq 0.01)$ TVFA 
compared with the control diet. Several of the treatments altered the molar proportions of individual VFA. Acetate decreased $(p \leq 0.03)$ on adding 2-NE, propynoic acid, p-coumaric acid, bromoform, AT, or lactic acid to the control diet. For all those treatments except p-coumaric acid and bromoform, there was a concomitant increase $(p \leq 0.05)$ in molar proportions of propionic and butyric acid compared with the control diet. Results of nitrate vs. zero nitrate treatment were: TVFA $2.91 \mathrm{vs.} 3.01 \mathrm{~mol}$, acetate $597 \mathrm{vs.} 604 \mathrm{mmol} / \mathrm{mol}$ propionate $250 \mathrm{vs.} 227 \mathrm{mmol} / \mathrm{mol}$ and butyrate $87 \mathrm{vs} .123 \mathrm{mmol} / \mathrm{mol}$.

The molar proportion of isobutyrate, isovalerate and valerate, and $\mathrm{NH}_{3}-\mathrm{N}$ for the control diet and experimental treatments are given in, Table 4 . The molar proportions of the branched-chain volatile fatty acids (BCVFA) were altered by many of the $\mathrm{CH}_{4}$ mitigating strategies tested. Compared to the control diet, isobutyrate increased $(p \leq 0.01)$ for p-coumaric acid treatment, while for bromoform treatment the molar proportion decreased $(p \leq 0.01)$. The treatments, $2-\mathrm{NE}$, propynoic, $\mathrm{p}$-coumaric, ferulic acid, AT, lactic acid, and lactic acid + acetic acid, increased $(p \leq 0.04)$, and bromoform decreased $(p \leq 0.01)$ the molar proportion of isovalerate compared to the control diet. Propynoic acid decreased $(p \leq 0.05)$ while bromoform and AT increased $(p \leq 0.05)$ molar proportion of valerate. Results of nitrate vs. zero nitrate treatment were: isobutyrate $6.63 \mathrm{vs.} 9.96 \mathrm{mmol} / \mathrm{mol}$, isovalerate $4.01 \mathrm{vs.} 4.94 \mathrm{mmol} / \mathrm{mol}$, valerate 16.4 vs. $16.3 \mathrm{mmol} / \mathrm{mol}$, and $\mathrm{NH}_{3}-\mathrm{N}$ concentration 436 vs. $557 \mathrm{mg} / \mathrm{L}$.

Tests for linear effects between the two levels according to Table 1 and the control diet ( 0 here) revealed no significant effect on in vitro $\operatorname{TOMD}(p=0.148)$ for all treatments (data not presented). However, there was a significant linear decrease $(p<0.01)$ in predicted in vivo $\mathrm{CH}_{4}$ production for propynoic acid (24 and $0 \mathrm{~mL} / \mathrm{g} \mathrm{DM})$ and p-coumaric acid $(27.1$ and $19.8 \mathrm{~mL} / \mathrm{g} \mathrm{DM})$ when the inclusion level was increased. 
Table 3. Effect of experimental treatments on predicted in vivo $\mathrm{CH}_{4}$ production (mL/g DM), in vitro true organic matter digestibility (TOMD, $\mathrm{g} / \mathrm{kg}$ ), total volatile fatty acid production (TVFA, mmol), and molar proportions of acetate, propionate, and butyrate ( $\mathrm{mmol} / \mathrm{mol}$ of TVFA) measured in $48 \mathrm{~h}$ gas from the in vitro incubation in experiment 1.

\begin{tabular}{|c|c|c|c|c|c|c|c|c|c|c|c|c|}
\hline \multirow{2}{*}{ Treatment } & \multirow{2}{*}{$\mathrm{CH}_{4}$} & \multirow{2}{*}{ TOMD } & \multirow{2}{*}{ TVFA } & \multirow{2}{*}{ Acetate } & \multirow{2}{*}{ Propionate } & \multirow{2}{*}{ Butyrate } & \multicolumn{6}{|c|}{$p$-Value ${ }^{1}$} \\
\hline & & & & & & & $\mathrm{C}_{\mathrm{CH} 4}$ & $\mathrm{C}_{\text {TOMD }}$ & $\mathrm{C}_{\text {TVFA }}$ & $\mathrm{C}_{\text {Acetate }}$ & $\mathrm{C}_{\text {Propionate }}$ & $\mathrm{C}_{\text {Butyrat }}$ \\
\hline Control & 38.7 & 867 & 3.62 & 583 & 237 & 125 & - & - & - & - & - & - \\
\hline 2-nitroethanol & 1.30 & 858 & 3.01 & 440 & 309 & 211 & $<0.01$ & 0.30 & 0.10 & $<0.01$ & $<0.01$ & $<0.01$ \\
\hline Nitrate $^{2}$ & 21.3 & 874 & 2.96 & 619 & 250 & 87 & $<0.01$ & 0.82 & NA & NA & NA & NA \\
\hline Propynoic acid & 13.9 & 839 & 2.57 & 476 & 297 & 209 & $<0.01$ & 0.25 & 0.01 & $<0.01$ & $<0.01$ & $<0.01$ \\
\hline Ferulic acid & 27.5 & 859 & 3.54 & 597 & 229 & 109 & 0.06 & 0.71 & 0.82 & 0.62 & 0.68 & 0.32 \\
\hline p-Coumaric acid & 24.2 & 763 & 3.01 & 492 & 176 & 121 & 0.01 & $<0.01$ & 0.10 & $<0.01$ & $<0.01$ & 0.82 \\
\hline Bromoform & 2.00 & 822 & 2.30 & 436 & 270 & 261 & $<0.01$ & $<0.01$ & $<0.01$ & $<0.01$ & 0.08 & $<0.01$ \\
\hline Fireweed & 38.1 & 858 & 4.01 & 583 & 226 & 140 & 0.34 & 0.69 & 0.24 & 0.99 & 0.55 & 0.34 \\
\hline Rowan berries & 28.9 & 843 & 3.71 & 586 & 241 & 117 & 0.96 & 0.35 & 0.80 & 0.93 & 0.82 & 0.64 \\
\hline A. taxiformis & 0.20 & 852 & 3.61 & 418 & 327 & 184 & $<0.01$ & 0.97 & 0.98 & $<0.01$ & $<0.01$ & $<0.01$ \\
\hline Rapeseed oil & 38.2 & 896 & 4.04 & 600 & 217 & 128 & 0.82 & 0.04 & 0.24 & 0.56 & 0.28 & 0.83 \\
\hline Dried distiller's grain & 35.3 & 877 & 3.74 & 549 & 241 & 152 & 0.43 & 0.48 & 0.73 & 0.66 & 0.91 & 0.33 \\
\hline Barley: oat & 37.4 & 863 & 3.66 & 596 & 225 & 124 & 0.73 & 0.73 & 0.89 & 0.65 & 0.51 & 0.98 \\
\hline Maize silage: grass & 30.7 & 846 & 3.71 & 577 & 240 & 136 & 0.61 & 0.56 & 0.80 & 0.84 & 0.87 & 0.48 \\
\hline Red clover: grass & 47.9 & 882 & 3.16 & 599 & 234 & 129 & 0.20 & 0.53 & 0.27 & 0.62 & 0.88 & 0.85 \\
\hline Lactic acid & 34.1 & 866 & 3.65 & 516 & 271 & 158 & 0.25 & 0.54 & 0.93 & 0.03 & 0.07 & 0.05 \\
\hline Lactic acid + acetic acid & 35.2 & 885 & 3.34 & 598 & 224 & 135 & 0.34 & 0.11 & 0.43 & 0.59 & 0.49 & 0.53 \\
\hline SEM & 1.75 & 4.3 & 0.120 & 7.2 & 4.2 & 5.5 & - & - & - & - & - & - \\
\hline
\end{tabular}

$\mathrm{NA}=$ not analyzed; SEM = standard error mean ${ }^{1}$ Orthogonal contrasts of control diet vs, treatment of the different in vitro traits. ${ }^{2}$ Nitrate treatment was compared to the zero nitrate diet made by adding urea and $\mathrm{CaCO}_{3}$ to the control diet according to Table 1; numerical differences of TVFA and molar proportions of volatile fatty acids are given in the text. 
Table 4. Effect of experimental treatments on molar proportions of isobutyrate, isovalerate, and valerate (mmol/mol of $\mathrm{TVFA})$, and ammonia concentration ( $\mathrm{NH} \mathrm{H}_{3}-\mathrm{N}$, $\mathrm{mg} / \mathrm{L}$ ) measured in $48 \mathrm{~h}$ gas from the in vitro incubation in experiment 1.

\begin{tabular}{|c|c|c|c|c|c|c|c|c|}
\hline \multirow{2}{*}{ Treatments } & \multirow{2}{*}{ Isobutyrate } & \multirow{2}{*}{ Isovalerate } & \multirow{2}{*}{ Valerate } & \multirow{2}{*}{$\mathrm{NH}_{3}-\mathrm{N}$} & \multicolumn{4}{|c|}{$p$-Value ${ }^{1}$} \\
\hline & & & & & $\mathrm{C}_{\text {Isobutyrate }}$ & $\mathrm{C}_{\text {Isovalerate }}$ & $\mathrm{C}_{\text {Valerate }}$ & $\mathrm{C}_{\mathrm{NH3}-\mathrm{N}}$ \\
\hline Control & 10.9 & 0.61 & 21.4 & 282 & - & - & - & - \\
\hline 2-nitroethanol & 5.16 & 2.77 & 16.4 & 436 & 0.80 & $<0.01$ & 0.14 & 0.39 \\
\hline Nitrate $^{2}$ & 6.63 & 4.01 & 16.43 & 270 & NA & NA & NA & NA \\
\hline Propynoic acid & 8.34 & 2.59 & 0.77 & 311 & 0.91 & $<0.01$ & $<0.01$ & 0.25 \\
\hline Ferulic acid & 14.4 & 5.23 & 20.0 & 320 & 0.88 & 0.03 & 0.67 & 0.98 \\
\hline p-Coumaric acid & 165 & 4.23 & 22.6 & 263 & $<0.01$ & $<0.01$ & 0.73 & 0.81 \\
\hline Bromoform & 0.00 & 0.00 & 28.7 & 302 & 0.64 & $<0.01$ & 0.03 & 0.17 \\
\hline Fireweed & 10.8 & 5.97 & 18.5 & 304 & 0.99 & 0.20 & 0.38 & 0.78 \\
\hline Rowan berries & 10.1 & 5.85 & 21.5 & 289 & 0.97 & 0.15 & 0.98 & 0.81 \\
\hline A. taxiformis & 5.95 & 5.33 & 35.4 & 354 & 0.83 & 0.04 & 0.00 & 0.52 \\
\hline Rapeseed oil & 13.3 & 8.32 & 19.1 & 319 & 0.92 & 0.08 & 0.49 & 0.25 \\
\hline Dried distiller's grain & 11.5 & 6.87 & 20.7 & 301 & 0.98 & 0.91 & 0.83 & 0.07 \\
\hline Barley: oat & 12.5 & 6.98 & 18.5 & 359 & 0.95 & 0.98 & 0.38 & 0.75 \\
\hline Maize: grass & 10.0 & 6.10 & 17.8 & 281 & 0.97 & 0.26 & 0.28 & 0.20 \\
\hline Red clover: grass & 9.04 & 5.23 & 14.6 & 306 & 0.94 & 0.06 & 0.08 & 0.45 \\
\hline Lactic acid & 9.30 & 5.29 & 21.3 & 323 & 0.94 & 0.03 & 0.97 & 0.86 \\
\hline Lactic acid + acetic acid & 8.95 & 4.61 & 16.7 & 282 & 0.93 & $<0.01$ & 0.16 & 0.77 \\
\hline SEM & 4.426 & 0.370 & 0.87 & 12.2 & - & - & - & - \\
\hline
\end{tabular}

$\mathrm{NA}=$ not analyzed; SEM = standard error mean. ${ }^{1}$ Orthogonal contrasts of control diet vs. treatment of the different in vitro traits. ${ }^{2}$ Nitrate treatment was compared to the zero nitrate diet made by adding urea and $\mathrm{CaCO}_{3}$ to the control diet according to Table 1; numerical differences molar proportions of branched-chain volatile fatty acids and $\mathrm{NH}$ - $\mathrm{N}$ are given in the text. 


\subsection{Experiment 2}

Predicted in vivo $\mathrm{CH}_{4}$ production decreased curvilinearly $(p<0.01)$ with increased levels of both 2-NE (Figure 1).

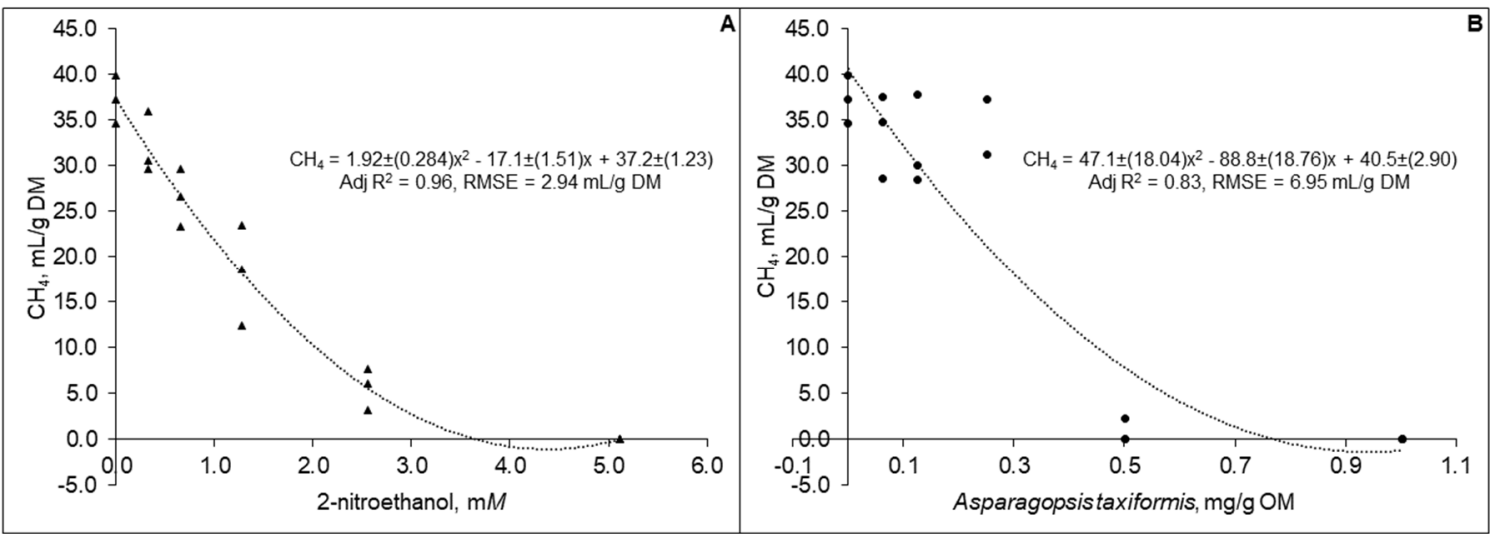

Figure 1. Predicted in vivo methane production based on analysis of $48 \mathrm{~h}$ gas from in vitro incubation of a control diet (545:363:92 g/kg of grass silage:barley:rapeseed meal) treated with different levels (three replicates per level) of (A) 2-nitroethanol and (B) Asparagopsis taxiformis in experiment 2.

The TVFA content decreased linearly $(p<0.01)$ from 5.35 to $3.00 \mathrm{mmol}$ at $48 \mathrm{~h}$ for 2 -NE and from 4.71 to $4.33 \mathrm{mmol}$ at $24 \mathrm{~h}$ for AT for the lower to higher level of supplementation (Figure 2). The TVFA content for 2-NE at $8 \mathrm{~h}\left(p<0.01\right.$; adj $\mathrm{R}^{2}=0.38$; RSME $\left.=0.22 \mathrm{mmol}\right)$ and $24 \mathrm{~h}\left(p<0.01\right.$; adj $\mathrm{R}^{2}=0.55$; RSME $=0.25 \mathrm{mmol}$ ) showed curvilinear responses, while for AT the curvilinear pattern was verified at $8 \mathrm{~h}\left(p<0.01 ; \mathrm{R}^{2}=0.55 ; \mathrm{RSME}=0.25 \mathrm{mmol}\right)$ and $48 \mathrm{~h}\left(p=0.01 ; \operatorname{adj} \mathrm{R}^{2}=0.33 ; \mathrm{RSME}=0.33 \mathrm{mmol}\right)$.

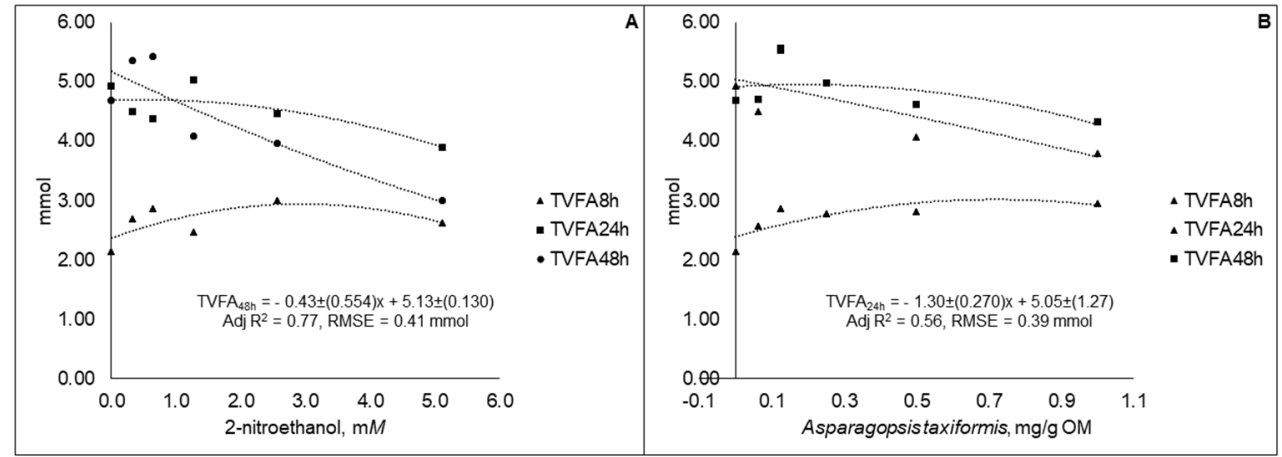

Figure 2. Total volatile fatty acid (TVFA) content in fluid samples taken at different time points during $48 \mathrm{~h}$ in vitro incubation of a control diet (545:363:92 $\mathrm{g} / \mathrm{kg}$ of grass silage:barley:rapeseed meal) treated with different levels (three replicates per level) of (A) 2-nitroethanol and (B) Asparagopsis taxiformis in experiment 2 .

Molar proportion of acetate decreased, while propionate and butyrate proportions increased curvilinearly $(p<0.01)$, at all-time points studied for 2-NE and AT (Figure 3). There were no statistical difference $(p>0.05)$ between the coefficients generated for the equations of the different time points. The best fit equations of molar proportions of VFA were generated for both 2-NE and AT from different sampling time points (Figure 3), but the equations generated were not statistically different $(p>0.05)$ from the other sampling time points (results not presented).

There were no linear or curvilinear relationships between TOMD and level of supplementation for 2-NE ( $p=0.152)$ or AT ( $p=0.142)$ (results not presented).

The equations of the molar proportions of BCVFA (isobutyrate, isovalerate, and valerate) were statistically different $(p<0.05)$ between the different sampling time points. The best fit equations are presented in Figure 4. 


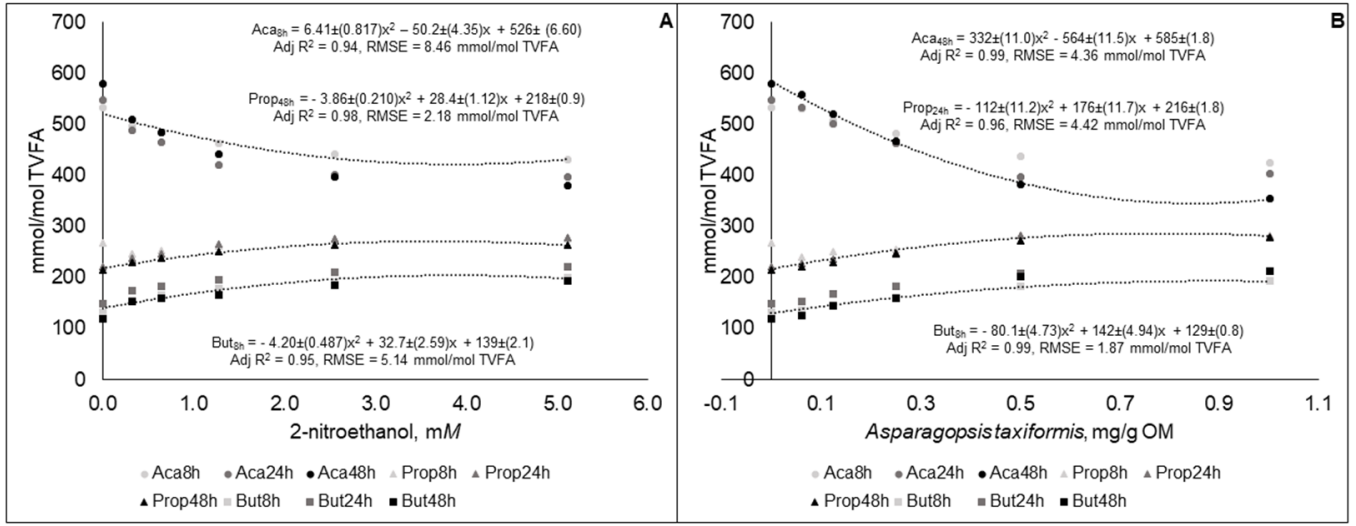

Figure 3. Molar proportions of acetate (Ace), propionate (Prop), and butyrate (But) in fluid samples gas samples taken at different time points during $48 \mathrm{~h}$ in vitro incubation of a control diet (545:363:92 $\mathrm{g} / \mathrm{kg}$ of grass silage:barley:rapeseed meal) treated with different levels (three replicates per level) of (A) 2-nitroethanol and (B) Asparagopsis taxiformis in experiment 2.

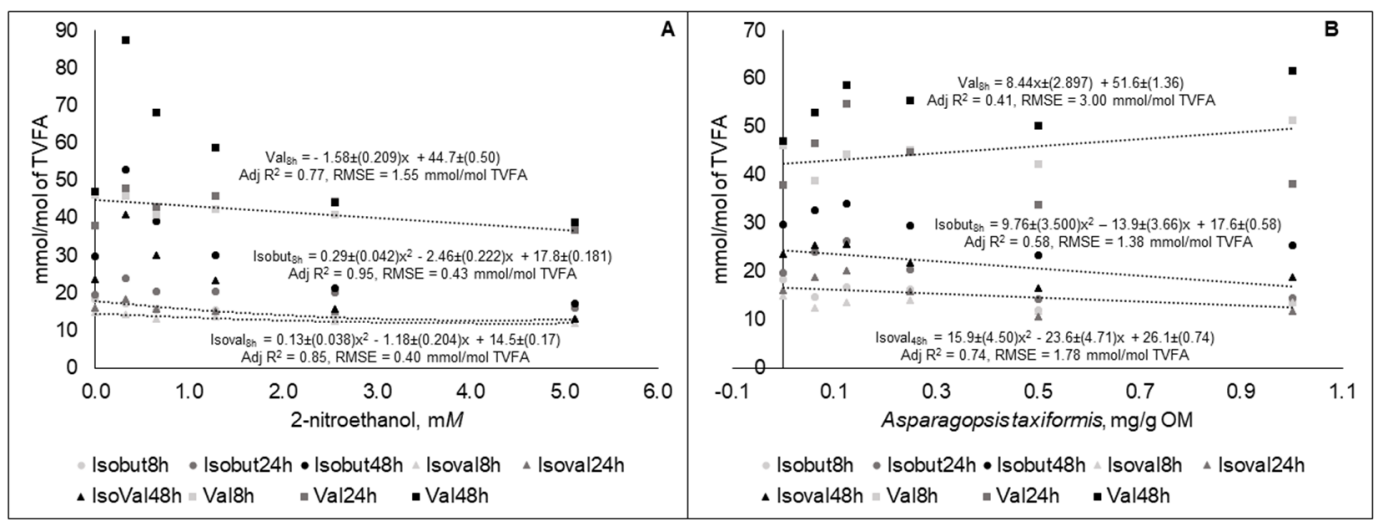

Figure 4. Molar proportions of isobutyrate (Isobut), isovalerate (Isoval), and valerate (Val) in fluid taken at different time points during $48 \mathrm{~h}$ in vitro incubation of a control diet (545:363:92 $\mathrm{g} / \mathrm{kg}$ of grass silage:barley:rapeseed meal) treated with different levels (three replicates per level) of (A) 2-nitroethanol and (B) Asparagopsis taxiformis in experiment 2.

The $\mathrm{NH}_{3}-\mathrm{N}$ concentration responses decreased linearly $(p<0.05)$ for both 2-NE and AT at both 8 and $24 \mathrm{~h}$, and the best fit equations are presented in Figure 5.

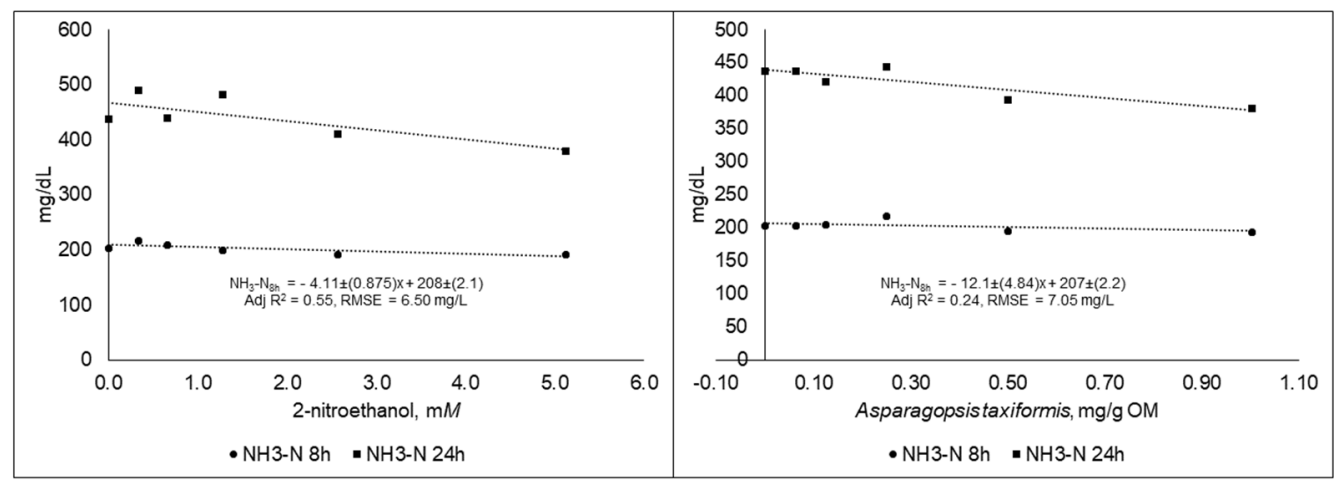

Figure 5. Ammonia concentration $\left(\mathrm{NH}_{3}-\mathrm{N}\right)$ in fluid samples taken at different time points during 48 $\mathrm{h}$ in vitro incubation of a control diet (545:363:92 $\mathrm{g} / \mathrm{kg}$ of grass silage:barley:rapeseed meal) treated with different levels (three replicates per level) of (A) 2-nitroethanol and (B) Asparagopsis taxiformis in experiment 2 . 


\section{Discussion}

The $\mathrm{CP}$ concentration of the potential $\mathrm{CH}_{4}$ reducing diets varied between 140 and $181 \mathrm{~g} / \mathrm{kg} \mathrm{DM}$, and reflected the characteristics of the dietary ingredient studied in each diets. Regarding that Peptone ${ }^{\mathrm{TM}}$ was included in the buffered rumen fluid, none of the diets supplied an insufficient amount of CP in terms of $\mathrm{CP}$ available for rumen microbial growth in comparison with in vivo requirements [22].

Ruminants are valuable food producers world-wide, since they are able to utilize fibrous non-human-edible resources (forages and pasture) through microbial fermentation of feed in the rumen. Recent data indicate that domesticated ruminants are not the major contributor to anthropogenic $\mathrm{CH}_{4}$ emissions. The fermentation of feed and decomposition of manure are the foremost sources of GHG emissions caused by domesticated ruminants [23]. Estimates suggest that livestock are responsible for around $9 \%$ and $37 \%$ of anthropogenic $\mathrm{CO}_{2}$ and $\mathrm{CH}_{4}$ emissions, respectively [24]. Long-term strategies to improve feed efficiency through targeted breeding [25] and improved longevity or lifetime productivity [26] could reduce $\mathrm{CH}_{4}$ emissions from dairy cows. According to Knapp et al. [9], nutrition and feeding approaches may be able to reduce $\mathrm{CH}_{4}$ emissions per unit of energy-corrected milk by $2.5-15 \%$, while reductions of $15-30 \%$ can be achieved by combined genetic and management approaches.

\subsection{In Vitro Measurements of $\mathrm{CH}_{4}$ Production in Ruminants}

This in vitro study evaluated a wide variety of dietary $\mathrm{CH}_{4}$ inhibitors, which would not have been feasible in an in vivo study. A main advantage of the in vitro gas production system in measuring $\mathrm{CH}_{4}$ emissions is that it provides a large number of data points, allowing accurate estimates of $\mathrm{CH}_{4}$ emissions. However, it is a batch culture approach and has some limitations compared with in vivo studies (e.g., no absorption of VFA over time). The in vitro method used here was developed by Ramin and Huhtanen [14] to overcome this problem and involves a modeling approach based on data obtained from the gas in vitro system. They assumed a gross energy concentration of $18.5 \mathrm{MJ} / \mathrm{kg} \mathrm{DM}$, while the predicted proportion of $\mathrm{CH}_{4}$ energy for a sample size of around $1000 \mathrm{mg}$ was calculated to be 0.061 . This value is close to observed in vivo values at production levels of intake in dairy cows [27]. Recently, Danielsson et al. [28] evaluated the in vitro technique developed by Ramin and Huhtanen [16] using data (diets) from in vivo studies using a respiration chamber to measure $\mathrm{CH}_{4}$ emissions. The results showed a high correlation $\left(R^{2}=0.96\right)$ between observed (chamber) data and predicted in vivo $\mathrm{CH}_{4}$ values, confirming that the in vitro system is a useful tool for screening diets and evaluating feed additives.

\subsection{Dietary Strategies to Decrease $\mathrm{CH}_{4}$ Production from Ruminants}

In this study, we screened many different dietary strategies with known potential to mitigate $\mathrm{CH}_{4}$ production from ruminants and also a few new potential inhibitors. It is known that improved forage quality, feeding balanced diets to ensure efficient utilization of nutrients, and optimized microbial protein synthesis in the rumen can decrease $\mathrm{CH}_{4}$ production in relation to animal productivity [29]. With respect to improved forage quality, the effects on $\mathrm{CH}_{4}$ production reported in the literature are contradictory. Enteric $\mathrm{CH}_{4}$ production increases with more digestible substrate available for rumen microbes, but overall emissions of $\mathrm{CH}_{4}$ in lactating dairy cows can decrease per $\mathrm{kg}$ increase in digestible OM [8]. The mechanism behind this effect is likely that better forage quality improves intake, and thereby increases passage rate. Increased passage rate (i.e., decreased feed retention) and larger animals (i.e., greater body mass) have been associated with reduced $\mathrm{CH}_{4}$ emissions in sheep [30-32].

Contrasted to our results, in measurements in vivo, rapeseed oil added at $50 \mathrm{~g} / \mathrm{kg}$ DM to a grass silage-based diet reduced ruminal $\mathrm{CH}_{4}$ emissions from lactating cows by $22 \%$ [33], with the reduction observed being entirely explained by decreases in DM intake and the dilution effect on fermentable $\mathrm{OM}$. Use of dried distiller's grain to replace soybean meal in diets based on grass silage decreased $\mathrm{CH}_{4}$ production in an in vitro study by Franco et al. [34]. The effect was explained by a shift in the ruminal fermentation pattern to decreased acetate and butyrate production and increased propionate 
production. A similar shift in ruminal fermentation pattern was observed when rapeseed meal replaced soybean meal in vitro in that study [35]. In the present study, dried distiller's grain replaced rapeseed meal in the control diet and the suggested similarities in ruminal fermentation pattern of these protein supplements would explain the lack of effect on predicted in vivo $\mathrm{CH}_{4}$ production. In contrast to our results, Fant et al. [35] observed a significant reduction in predicted in vivo $\mathrm{CH}_{4}$ production of $2.1 \mathrm{~mL} / \mathrm{g}$ DM when using oats instead of barley as the concentrate carbohydrate source. Inclusion of maize silage is also reported to promote propionate fermentation in the rumen, and thereby decrease $\mathrm{CH}_{4}$ production in dairy cows [36-38]. However, we did not observe this effect with inclusion of maize silage in the diets. Greater molar proportions of acetate and lower proportions of propionate in VFAs when replacing grass with red clover have been reported both in vivo [39] and in vitro [40], suggesting that $\mathrm{CH}_{4}$ production potential is greater when ruminants are fed red clover. Maize silage and red clover diets were only numerically lower respectively higher in in vivo predicted $\mathrm{CH}_{4}$ production compared with the control diet in this study. On the other hand, grasses are generally more likely to accumulate nitrates than legumes, and nitrate inhibits enteric $\mathrm{CH}_{4}$ production by replacing reduction of $\mathrm{CO}_{2}$ to $\mathrm{CH}_{4}$ as a major sink for disposal of $\mathrm{H}_{2}$ in the rumen [41]. Interactions between ruminant physiological responses and diet quality affecting $\mathrm{CH}_{4}$ production might explain the lack of impact on in vivo predicted $\mathrm{CH}_{4}$ production by the potential $\mathrm{CH}_{4}$-reducing diets screened in vitro in this study.

The chemical inhibitors 2-NE and bromoform, and the plant-derived inhibitor AT, gave a very large reduction in predicted in vivo $\mathrm{CH}_{4}$ production in this study. The bromoform concentrations of 1.5 and $3.0 \mathrm{mg} / \mathrm{kg}$ DM used in this study were representative of concentrations occurring naturally in AT [42]. Vucko et al. [43] analyzed bromoform concentrations in AT biomass subjected to a wide variety of post-harvesting processes and found a maximum concentration of $4.4 \mathrm{mg} / \mathrm{g}$ DM for unrinsed, frozen, and freeze-dried AT. Those authors suggest a bromoform threshold of $1.0 \mathrm{mg} / \mathrm{g}$ DM in AT for $100 \%$ inhibition of $\mathrm{CH}_{4}$ production in vitro, which corresponds with our results and the levels used in this study.

Machado et al. [44] tested different dosages of AT in vitro and found that production of $\mathrm{CH}_{4}$ was decreased by $84.7 \%$ at an inclusion level of $1 \%$ (OM basis), while at AT doses greater than $2 \%$ (OM basis), $\mathrm{CH}_{4}$ production was decreased by more than $99 \%$ compared with the control treatment. In the present study, in vivo predicted $\mathrm{CH}_{4}$ production was inhibited almost completely by AT already at a level of $0.5 \%$ on an OM basis. Li et al. [45] added AT to diets fed to sheep and observed a reduction of $\mathrm{CH}_{4}$ production at inclusion levels exceeding 1\% of OM intake, but with altered rumen fermentation at all inclusion rates, i.e., at inclusions $\geq 0.5 \%$ of OM intake. On the other hand, in a short-term in vivo experiment by Stefenoni et al. [46], inclusion of AT at $0.5 \%$ of DM intake decreased $\mathrm{CH}_{4}$ emission in lactating dairy cows by $80 \%$, with no negative effects on DM intake and milk yield (rumen fermentation parameters were not measured).

An in vitro study by Zhang and Yang [47] indicated high potential of 2-NE to mitigate $\mathrm{CH}_{4}$ production, as also found in the present study. However, they observed a negative effect on in vitro digestibility already at their lowest dose of $5 \mathrm{mM}$, which was not observed in this study. Use of 2-NE in an in vivo trial would not be realistic, considering that the concentration we used in vitro would equate to a daily dose of $0.9 \mathrm{~L}$ of 2-NE for a dairy cow with a rumen volume of $200 \mathrm{~L}$.

Except for molar proportion of valerate with increased AT supplementation, all of the BCVFA decreased with increased supplementation in the dose response experiment. The BCVFA are mainly a consequence of the degradation of the amino acids valine, isoleucine, leucine and proline and are used for the biosynthesis of those amino acids and higher branched chain volatile fatty acids. The BCVFA are specific nutrients for the ruminal cellulolytic bacteria, and are believed to have a general positive influence on microbial fermentation [48].

Nitrate, propynoic acid, and p-coumaric acid had much lower inhibitory effects on predicted in vivo $\mathrm{CH}_{4}$ production. Nitrate is reported to be an effective $\mathrm{CH}_{4}$ production mitigating dietary component [49,50]. For example, a 24.8\% reduction in $\mathrm{CH}_{4}$ production by lactating cows receiving nitrate at $21.1 \mathrm{~g} \mathrm{NO}_{3}{ }^{-} / \mathrm{kg}$ of DM was observed by Olijhoek et al. [51]. The dose of nitrate that can 
be toxic to ruminants' ranges between 198 and $998 \mathrm{mg} / \mathrm{kg}$ live weight and is dependent on diet, administration, and consumption [52]. However, the negative effects of nitrate can be reduced through gradual adaptation of animals to consumption of this nitrogen source, which could contribute to reducing $\mathrm{CH}_{4}$ emissions. The $\mathrm{CH}_{4}$ inhibitory effect of propynoic acid in this study was lower than that observed by Zhou et al. [53] at a comparable inclusion rate (75.7\% reduction compared with a control diet with no inhibitor added). Also the lower amount of TVFA compared with the control diet indicated that propynoic acid can potentially affect digestibility. The inhibitory effect of p-coumaric acid on $\mathrm{CH}_{4}$ production by ruminants has not been studied previously and there are no in vitro results with which to compare, but the treatment decreased the dietary TOMD. Lactate in the rumen are metabolized to propionate, which could hypothetical induce changes in ruminal fermentation pattern providing an alternative hydrogen sink to reduce methanogenesis. Likely, the lactic acid preservation has to be more extensive than the levels suggested in this study to have an effect on $\mathrm{CH}_{4}$ production in dairy cows.

\section{Conclusions}

This study confirmed that natural bioactives produced by the red seaweed Asparagopsis taxiformis can act as a strong natural inhibitor of $\mathrm{CH}_{4}$ production in domesticated ruminants. Use of $\mathrm{CH}_{4}$ inhibitors with high mitigation potential at a reasonable dietary supplementation level could be an important and effective strategy to mitigate $\mathrm{CH}_{4}$ emissions by ruminants. However, Asparagopsis taxiformis needs to be further evaluated in vivo to ensure it has no negative effects on animal health, productivity, or product quality. It is also important to establish the long-term $\mathrm{CH}_{4}$ mitigation effect of using this inhibitor.

Author Contributions: S.J.K.: conceived and supervised the study and acquired funding. S.J.K., J.C.C.: inputs to data analysis. S.J.K., M.R.: methodology. J.C.C., S.J.K., M.R.: conducted the experiment and wrote the full paper. Funding: This research was funded by FACCE ERA-GAS and FORMAS.

Acknowledgments: The authors would like to extend their sincere appreciation to Ann-Sofi Hahlin, Azam Jafari, and Amanda Poppi for their support in laboratory work, and to Carl Tryggers Foundation for providing a postdoc scholarship for J.C.C.

Conflicts of Interest: There is no conflict of interest relevant to this publication.

\section{References}

1. FAO. Food and Agriculture Organization of the United Nations. The State of Food Security and Nutrition in the World 2018. Available online: http://www.fao.org/3/i9553en/i9553en.pdf (accessed on 10 August 2019).

2. IPCC. Intergovernmental Panel on Climate Change. Climate Change 2013. Available online: https: //www.ipcc.ch/site/assets/uploads/2018/03/WG1AR5_SummaryVolume_FINAL.pdf (accessed on 10 August 2019).

3. Shindell, D. The social cost of atmospheric release. Clim. Chang. 2015, 130, 313-326. [CrossRef]

4. Howarth, R.W. Ideas and perspectives: Is shale gas a major driver of recent increase in global atmospheric methane? Biogeosciences 2019, 16, 3033-3046. [CrossRef]

5. Petrenko, V.V.; Smith, A.M.; Schaefer, H.; Riedel, K.; Brook, E.; Baggenstos, D.; Hart, C.; Hua, Q.; Buizert, C.; Schilt, A.; et al. Minimal geological methane emissions during the Younger Dryas-Preboreal abrupt warming event. Nature 2017, 548, 443-446. [CrossRef] [PubMed]

6. Henderson, G.; Cox, F.; Ganesh, S.; Jonker, A.; Young, W.; Global Rumen Census Collaborators; Janssen, P.H. Rumen microbial community composition varies with diet and host, but a core microbiome is found across a wide geographical range. Sci. Rep. 2015, 5, 14567. [CrossRef]

7. Johnson, K.A.; Johnson, D.E. Methane emissions from cattle. J. Anim. Sci. 1998, 73, 2483-2492. [CrossRef]

8. Ramin, M.; Huhtanen, P. Development of equations for predicting methane emissions from ruminants. J. Dairy Sci. 2013, 96, 2476-2493. [CrossRef] 
9. Knapp, J.R.; Laur, G.L.; Vadas, P.A.; Weiss, W.P.; Tricarico, W. Invited review: Enteric methane in dairy cattle production: Quantifying the opportunities and impact of reducing emissions. J. Dairy Sci. 2014, 97, 3231-3326. [CrossRef]

10. Shindell, D.; Kuylenstierna, J.C.; Vignati, E.; van Dingenen, R.; Amann, M.; Klimont, Z.; Anenberg, S.C.; Muller, N.; Janssens-Maenhout, G.; Raes, F.; et al. Simultaneously mitigating near-term climate change and improving human health and food security. Science 2012, 335, 183-189. [CrossRef]

11. IPCC. Intergovernmental Panel on Climate Change 2018. Available online: https://report.ipcc.ch/sr15/pdf/ sr15_spm_final.pdf (accessed on 10 August 2019).

12. Hristov, A.N.; Oh, J.; Giallongo, F.; Frederick, T.W.; Harper, M.T.; Weeks, H.L.; Brabco, A.F.; Moate, P.J.; Deighton, M.H.; Williams, R.O.; et al. An inhibitor persistently decreased enteric methane emission from dairy cows with no negative effect on milk production. Proc. Natl. Acad. Sci. USA 2015, 112, 10663-10668. [CrossRef]

13. Machado, L.; Magnusson, M.; Paul, N.A.; de Nys, R.; Tomkins, N. Effects of marine and freshwater macroalgae on in vitro total gas and methane production. PLoS ONE 2014, 9, e85289. [CrossRef]

14. Ramin, M.; Huhtanen, P. Development of an in vitro method for determination of methane production kinetics using a fully automated in vitro gas system-A modelling approach. Anim. Feed Sci. Technol. 2012, 174, 190-200. [CrossRef]

15. Menke, K.H.; Steingass, H. Estimation of the energetic feed value obtained from chemical analysis and in vitro gas production using rumen fluid. Anim. Res. Dev. 1988, 28, 7-25.

16. Cone, J.W.; Van Gelder, A.H.; Visscher, G.J.W.; Oudshoorn, L. Influence of rumen fluid and substrate concentration on fermentation kinetics measured with a fully automated time related gas production apparatus. Anim. Feed Sci. Technol. 1996, 61, 113-128. [CrossRef]

17. AOAC International. Official Methods of Analysis of AOAC International, 18th ed.; AOAC International: Gaithersburg, MD, USA, 2005; pp. 24-56.

18. Mertens, D.R. Gravimetric determination of amylase-treated neutral detergent fiber in feeds using refluxing in beakers or crucibles: Collaborative study. J. AOAC Int. 2002, 85, 1217-1240.

19. Krizsan, S.J.; Rinne, M.; Nyholm, L.; Huhtanen, P. New recommendations for the ruminal in situ determination of indigestible neutral detergent fibre. Anim. Feed Sci. 2015, 205, 31-41. [CrossRef]

20. Puhakka, L.; Jaakkola, S.; Simpura, I.; Kokkonen, T.; Vanhatalo, A. Effects of replacing rapeseed meal with fava bean at two concentrate crude protein levels on feed intake, nutrient digestion, and milk production in cows fed grass silage-based diets. J. Dairy Sci. 2016, 99, 7993-8006. [CrossRef]

21. Roque, B.M.; Salwen, J.K.; Kinley, R.; Kebreab, E. Inclusion of Asparagopsis armata in lactating dairy cows' diet reduces enteric methane emission by over 50 percent. J. Clean. Prod. 2019, 234, 132-138. [CrossRef]

22. Broderick, G.A.; Huhtanen, P.; Ahvenjärvi, S.; Reynal, S.M.; Shingfield, J. Quantifying ruminal nitrogen metabolism using the omasal sampling technique in cattle-A meta-analysis. J. Dairy Sci. 2010, 93, 3216-3230. [CrossRef]

23. Chang, J.; Peng, S.; Ciais, P.; Saunois, M.; Dangal, S.R.S.; Herrero, M.; Havlík, P.; Tian, H.; Bousquet, P. Revisiting enteric methane emissions from domestic ruminants and their $\delta^{13} \mathrm{C}_{\mathrm{CH} 4}$ source signature. Nat. Commun. 2019, 10, e3420. [CrossRef]

24. Kingston-Smith, A.H.; Edwards, J.E.; Huws, S.A.; Kim, E.J.; Abberton, M. Plant-based strategies towards minimising 'livestock's long shadow'. Proc. Nutr. Soc. 2010, 69, 613-620. [CrossRef]

25. Li, B.; Fikse, W.F.; Løvendahl, P.; Lassen, J.; Lidauer, M.H.; Mäntysaari, P.; Berglund, B. Genetic heterogeneity of feed intake, energy-corrected milk and body weight across lactation in Holstein, Nordic Red, and Jersey cows. J. Dairy Sci. 2018, 101, 10011-10021. [CrossRef] [PubMed]

26. Grandl, F.; Furger, M.; Kreuzer, M.; Zehetmeier, M. Impact of longevity on greenhouse gas emissions and profitability of individual dairy cows analysed with different system boundaries. Animal 2019, 13, 198-208. [CrossRef] [PubMed]

27. Yan, T.; Agnew, R.E.; Gordon, F.J.; Porter, M.G. Prediction of methane energy output in dairy and beef cattle offered grass silage-based diets. Livest. Prod. Sci. 2000, 64, 253-263. [CrossRef]

28. Danielsson, R.; Ramin, M.; Bertilsson, J.; Lund, P.; Huhtanen, P. Evaluation of an in vitro system for predicting methane production in vivo. J. Dairy. Sci. 2017, 100, 8881-8894. [CrossRef] [PubMed] 
29. Hristov, N.; Oh, J.; Lee, C.; Meinen, R.; Montes, F.; Ott, T.; Firkins, J.; Rotz, A.; Dell, C.; Adesogan, A.; et al. Mitigation of Greenhouse Gas Emissions in Livestock Production-A Review of Technical Options for Non-CO $\mathrm{CO}_{2}$ emissions; FAO Animal Production and Health: Rome, Italy, 2013; pp. 10-60.

30. Pinares-Patiño, C.S.; Ulyatt, M.J.; Lassey, K.R.; Barry, T.N.; Holmes, C.W. Rumen function and digestion parameters associated with differences between sheep in methane emissions when fed chaffed lucerne hay. J. Agric. Sci. 2003, 140, 205-214. [CrossRef]

31. Pinares-Patiño, C.S.; Ebrahimi, S.H.; McEwan, J.C.; Clark, H.; Luo, D. Is rumen retention time implicated in sheep differences in methane emission? In Proceedings of the New Zealand Society of Animal Production, Wellington, New Zeland, 24-26 June 2011; Volume 71, pp. 219-222.

32. Goopy, J.P.; Donaldson, A.; Hegarty, R.; Vercoe, P.E.; Haynes, F.; Barnett, M.; Oddy, V.H. Low-methane yield sheep have smaller rumens and shorter rumen retention time. Br. J. Nutr. 2014, 111, 578-585. [CrossRef]

33. Bayat, A.R.; Tapio, I.; Vilkki, J.; Shingfield, K.J.; Leskinen, H. Plant oil supplements reduce methane emissions and improve milk fatty acid composition in dairy cows fed grass silage-based diets without affecting milk yield. J. Dairy Sci. 2018, 101, 1136-1151. [CrossRef]

34. Franco, M.O.; Krizsan, S.J.; Ramin, M.; Spörndly, R.; Huhtanen, P. In vitro evaluation of agro-industrial by-products replacing soybean meal in two different basal diets for ruminants. In Proceedings of the 8th Nordic Feed Science Conference, Uppsala, Sweden, 13-14 June 2017; pp. 170613-170614.

35. Fant, P.; Ramin, M.; Jaakkola, S.; Grimberg, Å.; Carlsson, A.S.; Huhtanen, P. Effects of different barley and oat varieties on methane production, digestibility and fermentation pattern in vitro. J. Dairy. Sci. 2019, in press. [CrossRef]

36. O'Mara, F.P.; Fitzgerald, J.J.; Murphy, J.J.; Rath, M. The effect on milk production of replacing grass silage with maize silage in the diet of dairy cows. Livest. Prod. Sci. 1998, 55, 79-87. [CrossRef]

37. Beauchemin, K.A.; Kreuzer, M.; O’Mara, F.; McAllister, T.A. Nutritional management for enteric methane abatement: A review. Aust. J. Exp. Agric. 2008, 48, 21-27. [CrossRef]

38. Haque, M.N. Dietary manipulation: A sustainable way to mitigate methane emissions from ruminants. J. Anim. Sci. Technol. 2018, 60, 15. [CrossRef] [PubMed]

39. Vanhatalo, A.; Kuoppala, K.; Ahvenjärvi, S.; Rinne, M. Effects of feeding grass or red clover silage cut at two maturity stages in dairy cows. Nitrogen metabolism and supply of amino acids. J. Dairy Sci. 2009, 92, 5620-5633. [CrossRef] [PubMed]

40. Navarro-Villa, A.; O’Brian, M.; López, S.; Boland, T.M.; O'Kiely, P. In vitro rumen methane output of red clover and perennial ryegrass assayed using the gas production technique (GPT). Anim. Feed Sci. Tech. 2011, 168, 152-164. [CrossRef]

41. Allison, M.J.; Reddy, C.A.; Cook, H.M. The effects of nitrate and nitrite on VFA and $\mathrm{CH}_{4}$ production by rumen microbes. J. Anim.l Sci. 1981, 53, 391-399.

42. Machado, L.; Magnusson, M.; Paul, N.A.; Kinley, R.; Nys, R.; Tomkins, N. Identification of bioactives from the red seaweed Asparagopsis taxiformis that promote antimethanogenic activity in vitro. J. Appl. Phycol. 2016, 28, 3117-3126. [CrossRef]

43. Vucko, M.J.; Magnusson, M.; Kinley, R.D.; Villart, C.; Nys, R. The effects of processing on the in vitro antimethanogenic capacity and concentration of secondary metabolites of Asparagopsis taxiformis. J. Appl. Phycol. 2017, 29, 1577-1586. [CrossRef]

44. Machado, L.; Magnusson, M.; Paul, N.A.; Kinley, R.; de Nys, R.; Tomkins, N. Dose-response effects of Asparagopsis taxiformis and Oedogonium sp. on in vitro fermentation and methane production. J. Appl. Phycol. 2016, 28, 1443-1452. [CrossRef]

45. Li, X.; Norman, H.C.; Kinley, R.D.; Laurence, M.; Wilmot, M.; Bender, H.; Nys, R.; Tomkins, N. Asparagopsis taxiformis decreases enteric methane production from sheep. Anim. Prod. Sci. 2018, 58, 681-688. [CrossRef]

46. Stefenoni, H.; Räisänen, S.; Melgar, A.; Lage, C.; Young, M.; Hristov, A. Dose-response effect of the macroalga Asparagopsis taxiformis on enteric methane emission in lactating dairy cows. In Proceedings of the American Dairy Science Association Annual Meeting, Cincinnati, OH, USA, 23-26 June 2019; pp. W163, 378.

47. Zhang, D.F.; Yan, H.J. In vitro ruminal methanogenesis of a hay-rich substrate in response to different combination supplements of nitrocompounds; pyromellitic diimide and 2-bromoethanesulphonate. Anim. Feed Sci. Technol. 2011, 163, 20-23. [CrossRef] 
48. Andries, J.I.; Buysse, F.X.; DeBrabander, D.L.; Cottyn, B.G. Isoacids in ruminant nutrition: Their role in ruminal and intermediary metabolism and possible influences on performances-A review. Anim. Feed Sci. Technol. 1987, 18, 169-180. [CrossRef]

49. Newbold, J.R.; van Zijderveld, S.M.; Hulshof, R.B.A.; Fokkink, W.B.; Leng, R.A.; Terencio, P.; Powers, W.J.; van Adrichem, P.S.J.; Paton, N.D.; Perdok, H.B. The effect of incremental levels of dietary nitrate on methane emissions in Holstein steers and performance in Nelore bulls. J. Anim. Sci. 2014, 92, 5032-5040. [CrossRef] [PubMed]

50. Klop, G.; Hatew, B.; Bannink, A.; Dijkstra, J. Feeding nitrate and docosahexaenoic acid affects enteric methane production and milk fatty acid composition in lactating dairy cows. J. Dairy Sci. 2016, 99, 1161-1172. [CrossRef] [PubMed]

51. Olijhoek, D.W.; Hellwing, A.L.F.; Brask, M.; Weisbjerg, M.R.; Højberg, O.; Larsen, M.K.; Dijkstra, E.J.; Erlandsen, E.J.; Lund, P. Effect of dietary nitrate level on enteric methane production, hydrogen emission, rumen fermentation, and nutrient digestibility in dairy cows. J. Dairy Sci. 2016, 99, 6191-6205. [CrossRef] [PubMed]

52. Department of Climate Change, Commonwealth Government of Australia. The Potential of Feeding Nitrate to Reduce Enteric Methane Production in Ruminants. Available online: http://www.penambulbooks.com/ (accessed on 14 September 2019).

53. Zhou, Z.; Meng, Q.; Yu, Z. Effects of methanogenic inhibitors on methane production and abundances of methanogens and cellulolytic bacteria in in vitro ruminal cultures. Appl. Environ. Microbiol. 2011, 77, 2634-2639. [CrossRef]

(C) 2019 by the authors. Licensee MDPI, Basel, Switzerland. This article is an open access article distributed under the terms and conditions of the Creative Commons Attribution (CC BY) license (http://creativecommons.org/licenses/by/4.0/). 